\title{
„My się kochamy, jesteśmy parą gejów z pieskiem, a seksu nigdy nie uprawiamy".' \\ Męskość i seksualność w perspektywie aktywistów ruchów queerowych w Polsce
}

\author{
Justyna Struzik \\ Uniwersytet Jagielloński
}

\begin{abstract}
Niniejszy artykut stanowi próbę odpowiedzi na pytanie o charakterystyki polityk męskości obecnych w ruchach queerowych $w$ Polsce. Badam $w$ nim sposób, w jaki dziatacze ruchów definiuja i negocjuja własna tożsamość, a także opisuja dziatania kolektywne w odniesieniu do ich genderowego wymiaru. W części pierwszej artykułu krótko przedstawiam teorie odnoszace się do kategorii męskości, a także do genderowego ujęcia ruchów spotecznych. W części badawczej, opierając się na zebranych wywiadach z aktywistami $i$ aktywistkami ruchów queerowych, prezentuję różne postawy rozmówców - w odniesieniu do większej widoczności gejowskich tożsamości, obecności seksualności w dyskursach ruchów oraz do wewnętrznego zróżnicowania kategorii męskości nieheteronormatywnej.
\end{abstract}

\section{Wprowadzenie}

Artykuł stanowić będzie próbę przyjrzenia się temu, w jaki sposób aktywiści szeroko definiowanych ruchów queerowych ${ }^{2}$ w Polsce konstruują swoją męskość, oraz w jaki sposób definiują i negocjują jej miejsce i role w obrębie własnych działań. Ruchy społeczne, podobnie jak inne społecznie konstruowane fenomeny, mają także wymiar genderowy. Teza ta wydawać się może banalna jednak gdy przyjrzymy się sposobowi, w jaki bada się kolektywne działania, a także temu, jak się o nich pisze, możemy dojść do wniosku, że kwestia płci społeczno-kulturowej wciąż stosunkowo rzadko staje się główną osią analizy działań kolektywnych (Einwohner, Jocelyna, Olson 2000). Wyjątek stanowią tutaj oczywiście ruchy za cel stawiające sobie zmianę w obrębie porządku płci, w tym rozmaite ruchy feministyczne i męskie (Messner 1997; Wojnicka, Ciaputa 2011; Wojnicka 2013). Podobnie dzieje się w przypadku szeroko rozumianych ruchów queerowych - płeć definiowana jako konstrukt społeczny, pozostający w ścisłej zależności z seksualnością, stanowi dla badaczek i

\footnotetext{
${ }^{1}$ Cytat pochodzi z wywiadu z Markiem i Radkiem, aktywistami z Krakowa.

${ }^{2}$ Ruchy queerowe są definiowane tutaj jako szereg różnego rodzaju aktywności kolektywnych, które - poprzez różne strategie, polityki seksualne (np. polityki tożsamościowe lub polityki kłirowe) oraz formy działań -odnoszą się seksualności nienormatywnej i dążą do zmiany statusu quo. Znajdziemy więc w ich obrębie zarówno działania objęte ramą odnoszącą się do kategorii praw osób LGBT, jak i aktywności podważające same podwaliny porządku heteronormatywnego, dzielącego społeczeństwa na osoby heteroseksualne i homoseksualne.
} 
badaczy istotny obszar prowadzonych badań, dla samych działaczy i działaczek stając się często przedmiotem negocjacji granic działań oraz tożsamości kolektywnych (Gamson 1997; Taylor, Whittier 1992; Taylor 1999). To właśnie ruchom queerowym - ujętym w kontekście męskości poświęcę niniejszy artykuł, mając na uwadze, że męskość rzadziej niż kobiecość traktowana jest jako jeden z ważnych wymiarów tworzenia, rozwijania i funkcjonowania ruchów społecznych, i odbierana jest często jako przesłanka przezroczysta lub nieistotna w analizie (Nagel 1998; Taylor, Whittier 1998; Taylor 1999; Einwohner, Jocelyna, Olson 2000: 681). Przykładowo Joane Nagel, badaczka koncepcji narodu i nacjonalistycznych ruchów społecznych, zwraca uwagę na fakt, że termin gender jest w badaniach nad ruchami nacjonalistycznymi najczęściej odnoszony do kobiecości i kobiet, przy pominięciu kategorii męskości (1998: 242-243).

W artykule przyglądam się najpierw teoretycznej perspektywie, która z jednej strony zwraca uwagę na relację pomiędzy konstruowaniem płci a działaniami kolektywnymi - odpowiadając na pytanie o to, w jaki sposób możemy spoglądać na ruchy społeczne poprzez pryzmat genderu - z drugiej zaś strony włącza refleksję nad konstruowaniem (hetero)seksualności i płci, nadając im charakter przenikających się wzajemnie porządków społecznych (Jackson, Scott 2010). Następnie omówię wybrane koncepcje odnoszące się do kategorii męskości, rozumiejąc ją przy tym jako konfigurację wielu społecznych i kulturowych konstruktów definiujących to, co męskie. W części analitycznej odniosę się do badań jakościowych prowadzonych przeze mnie w latach 2012-2014 wśród aktywistów i aktywistek ruchów queerowych w Polsce. W analizie przyjrzę się m.in. temu, w jaki sposób granice męskości są negocjowane i przekraczane w obrębie ruchów queerowych.

\section{Gender a ruchy społeczne. Męskość w ruchu}

Na kilka istotnych kwestii zwraca uwagę literatura socjologiczna odnosząca się do genderowego wymiaru działań kolektywnych i uwzględniająca to, w jaki sposób płeć oraz tożsamość płciowa - w tym męskość - są konstruowane w obrębie ruchów społecznych. Po pierwsze pokazuje ona, w jaki sposób płeć może być czynnikiem determinującym mobilizację do działań kolektywnych uwzględniając przy tym, że samo znaczenie płci może stać się przedmiotem społecznych negocjacji w obrębie ruchów, zaś definicje kobiecości i męskości, dostarczone niejako przez społeczeństwo, mogą zostać odrzucone (Heath 2003; Fonow 1998). Po drugie, przyjmuje się, że sposób, w jaki ruchy mówią o płci w ideologiach bądź w ramach dyskursywnych (np. odnosząc się do jej tradycyjnego rozumienia lub też wprowadzając nowatorskie ujęcie), może mieć istotny wpływ na 
odbiór społeczny określonych działań kolektywnych przez konkretne publiczności, a także przyczyniać się do powstawania kontr-ruchów społecznych przedstawiających przeciwną wizję płciowości (Einwohner, Jocelyna, Olson 2000). Po trzecie, kolektywne działania funkcjonujące w obrębie sfery publicznej - wyrażając niezgodę na zastaną rzeczywistość i domagającc się zmiany w jej obrębie - nawet w najstarszych odsłonach utożsamiane są z męskością i aktywnościami mężczyzn. Jednakże ruchy, które najczęściej bywają poddawane analizie z perspektywy płci, aktywnie i bezpośrednio odnoszą się do polityk męskości lub kobiecości (Taylor 1999)³. Czerpiąc przykład z polityk seksualnych, również polityki męskości możemy rozumieć- w odniesieniu do ruchów społecznych - jako ramę, która zbiera znaczenia przypisane męskości, definiuje zakres palących problemów, ujawnia wizję zmian wymagających wprowadzenia, jak również wyszczególnia narzędzia i środki służące tym celom. Taka rama określa co - i w jaki sposób - owe ruchy mówią o męskościach, jak je konstruują, negocjują, dekonstruują i jakie tworzą hierarchie z nimi związane (Messner 1997; Robinson, Spivey 2007; Heath 2003).

W szeroko definiowanych działaniach kolektywnych - odnoszących się wprost do kategorii męskości i związanych z nimi ról społecznych (np. ojca, partnera, żołnierza) -wyróżnia się zazwyczaj dwa podstawowe typy ruchów stanowiących odpowiedź na współczesne przemiany dotyczące kobiecości i męskości oraz ról rodzinnych i intymnych. Owe ruchy często są wynikiem oddziaływania dyskursu feministycznego; do pierwszego typu zalicza się więc ruchy reakcyjne, antyfeministyczne, zaś do drugiego - ruchy prorównościowe (profeministyczne), uznawane zazwyczaj za prezentujące progresywną wizję męskości (Messner 1997, 1998). W przypadku tych pierwszych męskość przedstawiana będzie jako tożsamość w stanie kryzysu, co wywoła ujawnienie - najczęściej rozumianych tradycyjnie - żądań dotyczących odnowienia wzorów i praktyk męskości (Miles 1989: 51-54). Z kolei w przypadku ruchów prorównościowych, kryzys, jeśli się pojawi, będzie definiowany w kategorii szansy na - związaną z odrzuceniem patriarchalnych wzorów męskości zmianę w obrębie tożsamości i praktyk męskich (Wojnicka, Ciaputa 2011). Konieczne zdaje się podkreślenie, że podział ten stanowi jedynie uproszczony obraz męskich działań kolektywnych i nie uwzględnia ruchów lub grup mężczyzn stawiających sobie za cel, przykładowo, rozwój duchowy mężczyzn i budowę ich tożsamości (Wojnicka 2013).

\footnotetext{
${ }^{3}$ Wyjątek stanowią tutaj ruchy nacjonalistyczne, których męski wymiar jest coraz częściej brany pod uwagę przez badaczy i badaczki.
} 
Męskość, a właściwie męskości, nie są przez badaczy i badaczki postrzegane współcześnie jako homogeniczny, stabilny konstrukt społeczny, z przypisanymi do niego przywilejami, określonymi rolami i władzą instytucjonalną (Sinatti 2014). Męskości rozpatrywane są raczej jako - pozostające we wzajemnych relacjach, zróżnicowane, czasem wewnętrznie sprzeczne - społeczne porządki, które dodatkowo zmieniają się w zależności od lokalnych kontekstów politycznych, ekonomicznych czy kulturowych. Jedną z najbardziej znanych koncepcji męskości jest teoria porządku płci Raewyn Connell, która zakłada, że płeć społeczno-kulturowa stanowi swoistą strukturę umożliwiającą praktykowanie kobiecości i męskości (w liczbie mnogiej) w życiu codziennym (Connell 1995: 71-76; por. Kluczyńska 2011: 66-67). Pomiędzy ową strukturą a społecznym doing genders występuje silne powiązanie, jednak nie są one ze sobą tożsame - praktyka pozwala na negocjowanie strukturalnych wzorów płci w indywidualnym i społecznym doświadczeniu. W owym genderowym porządku wyróżnić możemy takie męskości, które zajmują w danym kontekście społecznym pozycje hegemoniczne, marginalne oraz pośrednie. W społeczeństwach patriarchalnych mamy do czynienia z męskością hegemoniczną (a więc z normatywnym ideałem związanym z władzą i przywilejami wybranej grupy mężczyzn), męskością podporządkowaną (stanowiącą zaprzeczenie hegemonicznej, pozbawioną atrybutów tradycyjnie przypisanych temu, co męskie, często odnoszoną w praktyce do przedstawicieli mniejszości etnicznych lub seksualnych), a także z męskością współuczestniczącą, której reprezentantom daleko jest, co prawda, do spełnienia wszystkich wymogów męskości hegemonicznych, ale przynajmniej częściowo i sytuacyjnie mogą oni wchodzić w dominujące role, tym samym wspierając status quo. Praktyki współuczestniczenia w odtwarzaniu męskości dominującej uwidaczniają się, przykładowo, w grupowych aktywnościach polegających na konkurowaniu z innymi mężczyznami o lepszy wynik w danej "grze" - a co za tym idzie - o lepszą pozycję w grupie (np. zawody w piciu alkoholu, zawody w "sikaniu na odległość" itd.) (por. Dempster 2011). Przegrani nie zajmują, co prawda, najlepszych pozycji w wytwarzanej hierarchii, ale podtrzymują zarysowane podziały, stając się częścią męskiej wspólnoty.

Wszystkie wspomniane typy męskości ujawniają się tak we wzajemnych relacjach, jak i w stosunku do kobiecości - nie stanowią więc "sztywnych ról” i należy je raczej rozumieć jako dynamiczne procesy społeczne (Messner 1993: 724-725).

Męskość homoseksualna najczęściej definiowania jest w kategoriach męskości podporządkowanych, a więc takich, które uznawane są w porządku genderowym za pozbawione 
cech przypisanych hegemonicznemu rozumieniu tego, co męskie. W patriarchalnych narracjach bycie gejem (czy też szerzej, bycie mężczyzną nieheteronormatywnym) odnosi się wciąż do „wybrakowanej męskości" - kategorii sytuowanej bliżej kobiecości w porządku genderowym. Jak pokazuje C.J. Pascoe, zawołanie „Dude, you're a fag" określa także tożsamość wołającego, ustalając granice "prawdziwej męskości” i legitymizując tożsamość mężczyzny heteroseksualnego (2005). Z kolei Hanna Lipowska-Teutsch, analizując praktykę „przecwelenia” obecną w więzieniach, pokazuje, w jaki sposób ów akt prowadzi do umiejscowienia „przecwelowanego” w pozycji, którą przypisuje się kobietom w społeczeństwie patriarchalnym (2012). Te przykłady doskonale obrazują, w jaki sposób nieheteronormatywna męskość konstruowana jest poprzez użycie odniesień i praktyk związanych z porządkiem płci.

Na skutek rozwoju i dywersyfikacji społeczności gejowskich coraz częściej przyjmuje się, że również tutaj nie mamy do czynienia z jednym wzorem męskości, lecz raczej z ich wielością, uwzględniającą także inne kategorie i tożsamości, takie jak: „rasa”, pochodzenie etniczne, klasowość, miejsce zamieszkania i wiek. Inne atrybuty mogą więc zostać przypisane osobie białej, cispłciowej i homoseksualnej pochodzącej z klasy wyższej, zaś w zupełnie odmiennej pozycji znajdzie się przedstawiciel mniejszości etnicznych przekraczający normy genderowe i reprezentujący klasę robotniczą (Heaphy 2011; Seidman 2012; Taylor, Hines, Casey 2010; Taylor 2011). W odniesieniu do ruchów queerowych - w zależności od używanych polityk seksualnych - wyodrębnić możemy kilka dominujących strategii działań, z których wyłaniają się z kolei różne polityki męskości. Wzorując się na ustaleniach zachodnich badaczy i badaczek, możemy przyjąć, że w przypadku tzw. polityki tożsamościowej będziemy mieli do czynienia nie tyle z całkowitym odrzuceniem męskości jako kategorii opresyjnej i wykluczającej, ale raczej z próbą reformowania tego, co kryje się pod tym pojęciem (Berstein 2009) ${ }^{4}$. Podobnie będzie w przypadku podziału na homo- i heteroseksualność, którego się wszakże nie podważa, a raczej wprowadza w jego obrębie zmiany w kierunku większej (różnie definiowanej) równości pomiędzy osobami heteroseksualnymi a osobami LGBT. Inny model polityki stanowić będzie polityka kłirowa ${ }^{5}$, odrzucająca - czy też negująca - nie tylko społeczny podział na homo i heteroseksualność, lecz także kontestująca znaczenia kategorii takich jak

\footnotetext{
${ }^{4}$ Według Mary Berstein (2009: 264-278) politykę tę należy określać nie jako politykę tożsamościową, ale raczej jako politykę wykorzystującą tożsamość w celach edukacyjnych i reformistycznych. Osobną politykę seksualną będzie stanowić krytyczna polityka, w której tożsamość znajdzie się w centrum pola krytyki.

${ }^{5}$ Stosuję fonetyczny zapis słowa queer, chcąc podkreślić lokalny charakter prezentowanych polityk - i odróżniając je tym samym od stosowania określenia queerowy w odniesieniu do różnorodnych praktyk, tożsamości i działań związanych ze społecznością LGBT. Zapis taki pojawiał się już wcześniej w literaturze naukowej (np. u Tomasza Sikory) oraz w aktywizmie polskim, np. w nazwie festiwalu Kłir Szyft organizowanego w Warszawie w 2008 roku lub w manifestach wrocławskiej grupy aktywistycznej Q Alternatywie.
} 
kobiecość czy męskość. Wyróżnienie tych dwóch polityk samo w sobie jest, oczywiście, pewnym uproszczeniem - przyjmuje się bowiem, że w praktyce ruchów queerowych mamy najczęściej do czynienia z ich hybrydycznymi odsłonami i mieszaniem się różnych idei na temat seksualności oraz kobiecości i męskości.

W odniesieniu do polskich ruchów queerowych, różni autorzy i autorki zwracają uwagę na kilka podstawowych kwestii łączących się - bezpośrednio lub pośrednio - z męskościami. Tomasz Basiuk, analizując możliwości przełożenia doświadczenia amerykańskich ruchów queerowych, podkreśla, że w polskim kontekście nie doszło - w przeciwieństwie na przykład do Stanów Zjednoczonych czy Wielkiej Brytanii - do wyraźnego rozłamu, czy nawet bardziej widocznych napięć, pomiędzy grupami/organizacjami gejowskimi (kierowanymi przez mężczyzn, pracującymi dla nich i z nimi), a społecznościami lesbijek (2012). Co więcej, niektórzy badacze podkreślają siłę koalicji, współpracy i solidarności pomiędzy organizacjami LGBT a organizacjami feministycznymi, obecną przykładowo w organizowaniu marszów w Poznaniu czy Krakowie (Binnie, Klesse 2012: 444-459). W przypadku ruchu na rzecz osób transpłciowych również wykazuje się, że ruch ten (tj. organizacje, inicjatywy, transaktywiści i transaktywistki) dość dobrze został przyjęty przez działaczy i działaczki gejowskolesbijskie (Basiuk 2012: 76). To jednak wciąż tylko jedna perspektywa na tę problematykę. Inne światło na tę kwestię rzucają badaczki piszące w ramach teorii feministycznych - podkreślając nie tylko zaskakujący brak ruchu lesbijskiego w Polsce (Gruszczyńska 2006, Struzik 2010), ale także większą widoczność mężczyzn i męskich tożsamości w ruchu (Wojnicka, Struzik 2011; Graff 2006). Taka perspektywa jest też częstokroć podnoszona przez same działaczki lesbijskie, które domagają się większej widoczności kwestii związanych z sytuacją kobiet nieheteronomatywnych - zarówno w przypadku ruchów queerowych, jak i ruchu feministycznego. W odpowiedzi na ten problem realizowane są inicjatywy adresowane w dużym stopniu wyłącznie do kobiet, jak np. festiwal O'Less, którego celem jest "rozpoznanie LESSkultury w Polsce”"

Pojawiają się także analizy wskazujące na to, że w Polsce działania i przekazy ruchów queerowych posiadają charakter cispłciowy, czyli taki, który nie tylko nie uwzględnia doświadczenia osób transpłciowych - czy też osób przekraczających normatywne wzorce kobiecości i męskości - ale także uznaje osoby cispłciowe za reprezentację społeczności LGBT (Dynarski 2014). Niejako obok tych trzech wymiarów współczesnych ruchów queerowych w Polsce, pojawiają się także analizy

\footnotetext{
${ }^{6}$ http://o-less.blogspot.com; dostęp: 30.11 .2014
} 
odnoszące się przede wszystkim do normatywnego wymiaru polityk seksualnych i polityk męskości, które to polityki w efekcie mają reprodukować wykluczające się - i wąsko definiowane - tożsamości gejowskie, sprowadzając je często do wzorów życia klasy średniej (Sikora 2012, Majka 2007/2008). W badaniach zachodnich wskazuje się w tym miejscu na rolę późnokapitalistycznych metropolii, w obrębie których aktywności społeczne zostają zawężone do konsumowania - wokół którego budowana jest (przynajmniej częściowo) także społeczność LGBT (Hennessy 1995, 2000).

\section{Metodologia badań}

W ramach badań jakościowych, stanowiących podstawę do prezentowanej analizy, przeprowadziłam jeden zogniskowany wywiad grupowy oraz 30 częściowo-ustrukturyzowanych wywiadów z aktywistami i aktywistkami działającymi w dużych miastach w Polsce. Związane i związani z ruchem identyfikowali się jako osoby między 21 a 43 rokiem życia; jako lesbijki, geje, osoby queer, trans-osoby oraz osoby heteroseksualne; jako osoby dobrze wykształcone i zaangażowane w różne aktywności społeczne (zazwyczaj w więcej niż jedną inicjatywę). Można powiedzieć, że wszystkie osoby reprezentowały klasę średnią z wysokim kapitałem kulturowym, studiowały, pracowały w szkołach wyższych - a często także w organizacjach pozarządowych i instytucjach kultury - zaś w sporadycznych przypadkach prowadziły własną firmę. Stosunkowo często jednak znajdowały się w sytuacji prekaryjnej (Standing 2014). Istotną częścią prowadzonych badań była także obserwacja uczestnicząca podczas licznych wydarzeń lokalnych, krajowych lub międzynarodowych. Miałam okazję wziąć udział w wielu festiwalach, dyskusjach, pokazach filmowych, marszach, nieformalnych (towarzyskich) spotkaniach, konferencjach i pracach organizacji pozarządowych. Uczestnictwo w "dziejącym się" ruchu społecznym pozwoliło mi dobrze poznać strukturę wewnętrzną realizowanych działań, ich dynamikę i cykliczność, a także zrozumieć złożone relacje $w$ ich obrębie. Stanowiło to także często wyzwanie dla mnie jako badaczki i aktywistki zarazem, stawiając mnie w sytuacji, w której musiałam negocjować własną pozycję i tożsamość w obrębie - i wobec - badanych ruchów (por. McCurdy, Uldan 2014). Istotny jest tu także fakt, że w prowadzonych badaniach przyświecała mi perspektywa publicznej socjologii queer, która stawia przed socjologią szereg pytań o możliwości wprowadzania bądź przyczyniania się do zmiany społecznej poprzez produkcję wiedzy (Santos 2012; Struzik 2012). Produkowana wiedza ma być nie tylko partycypacyjnie "wydobywana” niejako ze środka ruchów społecznych (a więc z udziałem z aktywistów i aktywistek), ale także prowadzić ma do powstawania „teorii-ruchu-dla- 
ruchu" (movement-relevant theory, zob. Bevington, Dixon 2005), tj. teorii ważnej dla wprowadzania kolektywnych zmian.

Wykorzystując analizę ramową, badałam także produkty ruchu, tj. ulotki, plakaty, manifesty, statusy organizacji, programy festiwali, symbole (por. Johnston 2002; Buechler 2011; Snow 2007; Valocchi 2005). Warto zaznaczyć, że podczas prowadzonych badań męskość nie stanowiła dla mnie kluczowego obszaru badawczego, a raczej - w trakcie wielu prowadzonych wywiadów z aktywistami i aktywistkami - niejako wyłaniała się w odniesieniu do problemów, z jakimi borykają się ruchy queerowe (np. niewidoczność kobiet nieheteroseksualnych przy równoczesnej większej obecności gejów w aktywnościach ruchów), jak również pojawiała się w związku z obecnością seksu i seksualności w dyskursie ruchów oraz w kontekście przyczyn indywidualnego zaangażowania w aktywności kolektywne.

Do niniejszego artykułu wybranych zostało 10 wywiadów z aktywistami, tj. osobami identyfikującymi się jako mężczyźni. Konieczne wydaje się jednak podkreślenie, że często ich stosunek wobec męskości - i tego, co jest rozumiane najczęściej pod tym terminem - był przedmiotem wielu negocjacji, refleksji i niezgody, powodując także przedefiniowywanie na nowo tego, co uznawane za męskie. Przykładowo Patryk związany z krakowską społecznością LGBT wskazuje, że „[moja] płeć [męska] jest w dokumentach, każda osoba ma ją zapisaną, ale ja nie mam jakichś szczególnych, szczególnego poczucia identyfikowania się [z męskością]. Wszędzie, gdzie nie jest to konieczne, w ogóle lubię nie zaznaczać" [W14_M29_KRK_Patryk] ${ }^{7}$.

W artykule nawiązuję także do narracji innych osób zaangażowanych w ruchy i identyfikujących się jako kobiety lub osoby queer, by uwzględnić również pozostałe głosy odnoszące się do męskości oraz męskiego wymiaru działań kolektywnych.

\section{Męskości: granice, negocjacje i tożsamość}

W analizowanych wywiadach przyglądałam się z jednej strony temu, w jaki sposób poszczególni aktywiści umiejscawiają własne doświadczenia bycia mężczyzną, czy też praktykowania męskości, w obrębie ruchów queerowych - zarówno w odniesieniu do indywidualnych biografii, jak i

${ }^{7}$ Oznaczenia wywiadów zawierają następujące informacje: W1 - numer wywiadu; M lub K - płeć osoby, z którą rozmawiałam; wiek; miasto, w którym dana osoba aktualnie działa (w przypadku cytowanych wywiadów, WAW - Warszawa, KRK - Kraków, BB - Białystok, TOR - Toruń). Na końcu podaję zakodowane imię rozmówcy lub rozmówczyni. 
społecznego kontekstu związanego z aktywizmem. Z drugiej strony, stawiałam pytania dotyczące wizji zmian, jakie - ich zdaniem - mogą przynieść ruchy queerowe. Pytałam również o miejsca polityk męskości w obrębie tych ruchów. Innymi słowy, interesowało mnie, w jakim stopniu męskość stanowi część wypracowywanych celów i wizji, jak również ciekawiło mnie to, jaka idea lub idee - jej dotyczące wyłaniają się z narracji moich rozmówców. Wszyscy moi rozmówcy zwracali uwagę na płeć jako na jeden z istotnych wymiarów ruchów queerowych. Wśród zebranych opowieści odnaleźć można całe kontinuum definicji problematyki męskości i kobiecości, a także pełen przekrój ograniczeń używania tych kategorii w ruchach queerowych. Dla części osób, z którymi miałam okazję rozmawiać, męskość pojawiała się, z jednej strony, w kontekście wykluczenia i niewidoczności kobiet nieheterormatywnych, z drugiej zaś w odniesieniu do stosunkowo silnej pozycji mężczyzn - liderów danych organizacji czy grup (często w ramach historii z przeszłości). Inni z kolei zwracali uwagę na bezpośrednią mizoginię oraz inne formy dyskryminowania obecne wśród działaczy i działaczek, a także opowiadali o braku różnorodności tożsamości męskich, o braku subkultur seksualnych i praktyk nienormatywnych oraz o dominacji jednego wzoru męskości gejowskiej w działaniach i produktach ruchów queerowych.

\section{Od prywatnego do politycznego. Od mizoginii do feminizmu}

Dla wielu moich rozmówców i rozmówczyń, to prywatne biografie i doświadczenia były kluczowe w podejmowaniu decyzji o aktywnym włączeniu w działania ruchów queerowych. Często jednak takie doświadczenie poprzedzało zaangażowanie w inne aktywności społeczne. Możliwość działania queerowego była także rozpatrywana jako okazja do zmierzenia się z własnymi uprzedzeniami, przekonaniami na temat męskości i seksualności. Mówi o tym m.in. Kamil, który przyznaje, że działania w ruchach queerowych otworzyły go poniekąd na własną tożsamość płciową i pozwoliły przyjrzeć się dokładniej pozycji w społeczeństwie oraz w danej grupie:

Bardzo intensywnie w pewnym momencie przetwarzałem sobie, w takich dwóch kanałach, kwestie związane z genderem. Jeden to był taki akademicki, który gdzieś tam był dla mnie zawsze bardzo ważny i mocno do mnie przemawiający, ale też taki interpersonalny, gdzie z jednej strony akademicko, z drugiej strony na własnym doświadczeniu działackim wiele rzeczy sprawdzałem, przeżywałem i sobie tam eksplorowałem, chociaż miałem takie doświadczenie, kiedy byłem sam w kilku...wielu grupach jedynym mężczyzną w grupie bardzo wielu kobiet i to też, 
jak się tym różnym sytuacjom zacząłem przyglądać, to też ...tam się działy różne rzeczy, procesy, które mi pozwoliły bardziej zrozumieć działanie genderu, no mówiąc ogólnie. [W10_M29_WAW_Kamil]

Część rozmówców zwracała uwagę na fakt, że moment aktywnego zaangażowania się w działania ruchów był dla nich w pewnym sensie przełomowy, i wiązał się nie tylko z myśleniem o swojej płci i seksualności w sposób bardziej refleksyjny, ale także pozwolił im na ustosunkowanie się do pełnionych przez nich samych ról społecznych:

Ja mam 28 lat. To nie jest dużo, natomiast przez ten czas, od kiedy ja jestem świadomym siebie gejem i działam i obserwuję, jak się społeczeństwo zmienia, jestem pod wrażeniem, bo jest duża zmiana. Od kilku lat wstecz, kiedy w parach zadawano pytanie, kto pełni rolę mężczyzny, kto kobiety w związku, przez w ogóle odsuwanie tego tematu, poprzez to, że jest to temat, na który się wypowiada premier, nie tylko na Twitterze, ale na posiedzeniu Sejmu [W11_M28_WAW_Maciek]

Mimo wskazywanej autorefleksyjności, jednym z głównych i częstych motywów - pojawiających się w zebranych narracjach w odpowiedzi na pytanie o wewnętrzne trudności, problemy i wyzwania (stojące zarówno przed ruchami queerowymi rozumianymi jako zbiór różnego rodzaju działań, jak i przed poszczególnymi organizacjami i grupami nieformalnymi) - było spostrzeżenie, że „kwestie genderowe" wciąż zdają się być nierozwiązane i stosunkowo rzadko dyskutowane wśród aktywistów oraz aktywistek. Problem ten podnoszony był - tuż obok kłopotów z mobilizacją i zaangażowaniem dużej ilości osób w działania ruchów - zarówno przez aktywistki, jak i aktywistów; niekoniecznie wiązał się on jednak z pogłębioną refleksją nad własnym doświadczeniem i miejscem w ruchach, nad własnym doing gender ${ }^{8}$, a raczej mógł stanowić efekt bliskiej współpracy z ruchem feministycznym i znajomością dyskursu feministycznego wśród moich rozmówców i rozmówczyń (por. Binnie, Klesse 2012). Świadczyć o tym może fakt, że do kategorii męskości bezpośrednio odnoszono się stosunkowo rzadko, zaś "problem genderowy” oznaczał najczęściej "niewidoczność kobiet i osób transgenderowych" i nie był adresowany wprost do pozycji oraz statusu mężczyzn w ruchach. Na wywołanie tego problemu podczas wywiadów mogłam również mieć bezpośredni

${ }^{8}$ Działaczki, które chętniej przywoływały swoje wspomnienia związane z aktywizmem, częściej odnosiły się do własnych doświadczeń i konkretnych wydarzeń. 
wpływ - jako osoba związaną z organizacjami feministycznymi (Fundacją Przestrzeń Kobiet), ale także badaczka zajmująca się, przykładowo, kwestią niewidoczności lesbijek czy wykluczeniem kobiet nieheteroseksualnych spoza dużych miast. Istotnie, znajomość mojej działalności - zarówno aktywistycznej, jak i badawczej - mogła być w niektórych przypadkach przyczyną przywoływania "spraw genderowych" na pierwszym miejscu listy kwestii istotnych dla ruchów.

W kilku przypadkach przedstawiano w tym kontekście działania kolektywne w perspektywie dwóch faz, przez jakie - według moich rozmówców i rozmówczyń - miały przejść ruchy queerowe w Polsce. Pierwszą fazę odnoszono przede wszystkim do działań organizacji (np. w Warszawie lub Krakowie), które początkowo kierowane były przez mężczyzn-aktywistów mających duże poczucie sprawstwa i władzy, co często prowadziło do marginalizacji lesbijek, osób biseksualnych, a także osób transpłciowych (o ile te ostatnie w ogóle pojawiały się w ruchach). Jednakże, wraz z pojawianiem się coraz większej liczby nieformalnych grup i organizacji, w ciągu ostatnich kilku lat doszło do przejścia do fazy drugiej, w której, co prawda, "problem” nadal stanowią kwestie związane z męskością i kobiecością, a także z przekraczaniem norm genderowych, lecz w której kobiety jednak stają się bardziej widoczne na poziomie organizowania działań i podejmowania decyzji. Mimo że kilka osób podkreślało problem "[braku] takiego różnicowania na potrzeby kobiet, mężczyzn i osób, które się nie definiują ani jako kobieta, ani jako mężczyzna" [W8_K30_WAW_Tamara] oraz „[poczucia], że my jesteśmy jakimiś lesbijkami, że lesbijki są nieważne, że on jest liderem" [W9_K30_KRK_Anika], to jednak w kilku wypowiedziach - zarówno kobiet, jak i mężczyzn - kładziony jest nacisk na zmianę w organizacjach LGBT, które wcześniej zarządzane były przez silnego lidera męskiego, zaś dziś są kierowane w sposób bardziej inkluzywny i partycypacyjny (włączający zarówno kobiety, jak i osoby transgedenderowe). W odniesieniu do tej zmiany, Kamil, związany z warszawską Kampanią Przeciw Homofobii $(\mathrm{KPH})$, w następujący sposób opowiada o swojej przerwie w aktywizmie queerowym:

Teraz z perspektywy czasu mogę powiedzieć i to jest dla mnie o wiele bardziej przejrzyste, że wyleciałem, bo nie znałem zasad gry. A te zasady gry były związane - tak to sobie tłumaczę -, (że) gdzieś to się w historii organizacji, wiem, że nie tylko tej organizacji, ale też innych, czy innej bardzo dużej organizacji LGBT po prostu....kiedy jest za dużo mężczyzn, którzy mają w organizacji coraz większą władzę, czy większą, powiedzmy, decyzyjność, no to pomiędzy nimi się...robią 
tarcia, tak? No i ja tak sobie myślę, że po prostu coraz lepiej się tam czułem i coraz więcej miałem do powiedzenia, nie miałem jakichś problemów z konfrontacją...z wyrażaniem własnego innego zdania... [W10_M29_WAW_Kamil]

Według Kamila już sama obecność w organizacji kilku mężczyzn sprawia, że zaczynają oni rywalizować między sobą o wpływ na podejmowane decyzje. KPH jest największą polską organizacją, która działa na rzecz osób LGBT poprzez: „rzecznictwo polityczne, społeczne i prawne, tworzenie i wdrażanie systemowych rozwiązań edukacyjnych dla różnych grup zawodowych oraz budowanie szerokiego ruchu sojuszniczego" ${ }^{\prime 9}$. Przez długi czas była ona organizacją sieciującą i posiadającą oddziały w kilkunastu miastach Polski. Z czasem poszczególne lokalne jednostki zaczęły przeradzać się w niezależne organizacje lub grupy nieformalne. Kamil, nawiązując do tej zmiany, zauważa, że wiele lokalnych grup było przejmowanych przez mężczyzn („zapewne nieświadomie, to pewne..." [W10_M29_WAW_Kamil]) i to oni stawali się nowymi liderami - przy równoczesnym spychaniu kobiet i osób transgender poza granice widoczności. Nieco inne spojrzenie wnoszą aktywiści związani z krakowskim środowiskiem aktywistycznym, biorący udział m.in. w przygotowaniach festiwalu Queerowy Maj, którzy to mówią wprost o antyfeministycznej perspektywie obecnej wśród niektórych działaczy gejowskich:

Radek: Moim głównym problemem w Polsce, w tej chwili wewnętrzna homofobia, wewnętrzna transfobia i wewnętrzna mizoginia, które są dla mnie przerażające, są dla mnie bardzo szkodliwe dla społeczności LGBTQ i dla ruchu, ale też są szkodliwe dla innych osób, ponieważ jeśli my się tak zachowujemy, to też niszczymy poniekąd ruch feministyczny. Niszczymy poniekąd też inne ruchy społeczne, które o coś walczą...

Marek: No np. [według mnie] działacze gejowscy, którzy są antyfeministyczni...

R: Tak, dokładnie to jest...

M: Nie wspominając już o lesbijkach...

R: Nie tyle antyfeministyczni, co mizoginiczni po całości, tak. Nienawidzą kobiet. No ale też to, że w Polsce nigdy nie wykreowały się, nie wykreowało się rozumienie subkultur wewnątrz społeczeństwa...[(W4_M21_KRK_Marek; W4_M23_KRK_Radek]

\footnotetext{
${ }^{9}$ http://www.kph.org.pl; dostęp: 30.11.2014.
} 
Moi rozmówcy definiowali "mizoginiczne" podejście wśród aktywistów przywołując głównie brak otwartości na większe zróżnicowanie w subkulturach seksualnych, jak również podkreślając podtrzymywanie większej niewidoczności kobiet i osób trans w działaniach ruchów.

„Kwestia genderowa” stosunkowo częściej była jednak podnoszona przez działaczki, które zwracały uwagę na niewidoczność kobiet - wliczając w to osoby, które przekraczają normy genderowe. Agata wspominała o tym podczas wywiadu grupowego w Toruniu:

Z drugiej strony dla mnie to też jest kwestia takiego ruchu LGBT i pozycji kobiet w tym ruchu. Mam wrażenie, że jakby stereotypowo w ruchu LGBT, tak ogólnie, to są tylko źli, niedobrzy, zdeprawowani geje, których idolem jest Robert Biedroń i tak właściwie nic poza tym właściwie nie ma, tak. I nawet jeżeli chodzi o takie środowisko stricte lesbijskie, kobiet, czy kobiet transseksualnych czy biseksualnych, no, w ogóle coś takiego jak transseksualna kobieta nie istnieje w przestrzeni, nawet jeżeli mówimy o znanych lesbijkach, to właściwie nie ma takich osób. Jakby w takim heteroseksualnym otoczeniu ludzie są w stanie wymienić iluś tam znanych gejów. Tu był Poniedziałek, tu Biedroń, tu ktoś tam, tu ktoś tam, a pytanie o lesbijki? No właściwie nie ma takiej kobiety. [F1_K31_TOR_Agata]

W przypadku rozmówczyń podnoszono także potrzebę dyskusji na temat innych wykluczeń w obrębie ruchów queerowych. Respondentki podkreślały konieczność rozszerzenia działań pomocowych, tak by objęły one osoby z niepełnosprawnościami, niezamożne czy mieszkające w małych miastach i wsiach. Taka perspektywa rzadziej pojawiała się w narracjach aktywistów. W trakcie prowadzonych badań przyglądałam się również różnorodnym politykom seksualnym obecnym w ruchach w Polsce. Tzw. polityki kłirowe - podważające konieczność działania w oparciu o tożsamości wąsko zdefiniowane, takie jak np. gej czy lesbijka - podnoszone były przez działaczki i osoby identyfikujące się jako queer. Tego typu działania miałyby być według nich odpowiedzią na "Straszliwie głównonurtowe [...] wydarzenia, na łamach których przedstawia się emancypację przede wszystkim jako funkcję emancypacji ekonomicznej” i na "[...] wydarzenie, w którym większość zdarzeń jest skierowana dla gejów" [W1_K39_WAW_Róża]. Często istotną częścią polityk męskości, wyłaniających się z wypowiedzi działaczy ruchów queerowych, były wizje dotyczące samego 
aktywizmu. Z jednej strony, jak zostało pokazane powyżej, wielu z moich rozmówców jest świadomych większej widoczności gejów-aktywistów w dyskursie publicznym, jak również pomijania doświadczenia kobiecego i wykraczającego poza normy genderowe. Podobnie jak działaczki, oni również wskazywali na istotność włączania perspektywy feministycznej do działań na rzecz osób LGBT, a także na istotność współpracowania z organizacjami kobiecymi. Z drugiej jednak strony - ze względu różnorodność obecnych polityk seksualnych, a także zróżnicowanie badanych przeze mnie inicjatyw - wizje dotyczące zarówno współpracy z innymi ruchami społecznymi, jak i samych ruchów queerowych nie mogą zostać sprowadzone do jednej, wspólnej idei. W wywiadach pojawiała się kwestia m.in. separatystycznych działań skierowanych, przykładowo, tylko do kobiet lub tylko do mężczyzn. Moi rozmówcy bardzo często odnosili się w swoich refleksjach do historii ruchów zachodnich i doświadczeń aktywizmu transnarodowego. Zdaniem Maćka, związanego ze stowarzyszeniem „Miłość nie wyklucza”, tworzenie odrębnych inicjatyw w kontekście polskim nie jest konieczne - ze względu na stosunkową dużą wewnętrzną otwartość - mimo że kwestie związane z wykluczeniem wewnątrz ruchów są wciąż za rzadko dyskutowane:

Że gdzieś widzę, że w tych ruchach nawet kiedy te proporcje nie są równe, to są i mężczyźni i kobiety, i są te osoby trans, i raczej nie ma transfobii, tych może osób trans jest mniej, ale jakby nie ma dyskusji nad tym, że nie wiem, nie powinno ich być, nie ma dyskusji nad tym, nie wiem...w organizacjach, tak? Nie mówię, że w wielkiej społeczności nad tym [się nie dyskutuje], czy drag queen na Paradzie nie jest zbyt przegięte. Tego typu rzeczy, tak? No a po prostu miałem takie dziwne momenty, kiedy będąc na jakiejś...w tych krajach zachodnich, po prostu dowiadywałem się, że w organizacji nie ma kobiet, dlatego, że jest inna organizacja, w której są kobiety. No kurwa, w Berlinie! Albo że w tej organizacji też nie ma Turków, dlatego że oni mają swoją własną organizację, zresztą "oni mają takie roszczeniowe podejście". To mi się w pale nie mieściło, jak słyszałem takie rzeczy. Tutaj może nie widzę jakiejś ogromnej różnorodności, ale widzę otwartość na pewno i gotowość do właśnie takiego inkluzywnego działania, i to myślę o różnych organizacjach. [W11_M28_WAW_Maciek] 
Odmiennego zdania są krakowscy aktywiści, którzy wspominają sytuację próby włączenia do działań osób queer wykraczających poza normy kobiecości i męskości, dla których seks i seksualność były jednym z obszarów działań ruchów queerowych. Działacze obawiali się wówczas reakcji ze strony swoich kolegów i koleżanek z lokalnej organizacji, według których - ich zdaniem temat seksu nie powinien otwarcie stanowić kwestii, którą należy się zająć. Rozmówcy łączyli taką postawę z normatywnym rozumieniem tożsamości:

Marek: My się baliśmy, bo to były osoby stricte queerowe, tak. Nie o tożsamości cis i się po prostu baliśmy, że oni w zderzeniu z Fundacją, a konkretnie z zarządem po prostu...

Radek: Czysto queerowe i np. też interesujące się...

M: Seksualnością...

R: Seksualnością, jakimiś fetyszami, szerzej pojętym seksem i erotyzmem, i to też jest straszne tabu u nas według mnie, [tabu] seksualności...

M: Według mnie też...

R: Ponieważ to jest ten wizerunek ruchu LGBT, który jest odseksualizowany...

M: Że będę brutalny, "my się kochamy, my się nie pieprzymy"

R: Tak, my się kochamy, jesteśmy parą gejów z pieskiem. a seksu nigdy nie uprawiamy.

M: [...] jest coś takiego, że seks jest zły. [W4_M21_KRK_Marek; W4_M23_KRK_Radek]

Temat seksu i seksualności, jeśli się pojawiał w zebranych narracjach, łączony był najczęściej z męskością homoseksualną. Z jednej strony podkreślano - jak w przypadku Marka i Radka, a także Maćka, Darka i Patryka - że w ruchach dominuje obraz "odseksualizowany”, „zachowawczy jesteśmy piękni i ładni wszyscy" [W11_M28_WAW_Maciek], "tu jesteśmy piękni i wspaniali” [W14_M29_KRK_Patryk] i prezentujący konserwatywną wizję męskiej seksualności (kobieca seksualność pojawiała się jedynie w kategoriach niewidoczności lub też "odzyskiwania seksualności kobiet" [W5_K43_WAW_Magda]). Z wypowiedzi aktywistów wnioskować można, że męskie ciało seksualizacji podlega, co prawda, w dyskursie medialnym i komercyjnym - choćby w reklamach produktów kierowanych do społeczności gejowskiej - jednak przedstawiane jest ono w wersji nieprzekraczającej norm genderowych. Taki też wizerunek bywa przyswajany przez same ruchy, tym 
samym tracąc często polityczny potencjał. Oznacza to, że praktyki cielesne i seksualne związane z homoseksualnością łatwiej jest przedstawić w ich komercyjnej odsłonie - dzięki narzędziom dostarczanym przez kapitalizm (i jako takie tworzonym w obrębie dyskursu publicznego) - aniżeli przykładowo w kategoriach praw bądź walki o sprawiedliwość seksualną. Odzwierciedla to szerszą tendencję prywatyzacji praw i sprawiedliwości seksualnej - w polskim społeczeństwie stosunkowo powolne zmiany odnośnie uznania praw osób LGBT występują równolegle z rosnącą komercjalizacją seksualności nienormatywnej, pozwalającej jednostce chronić, rozwijać i afirmować swoją tożsamość. Łatwiej jest więc doświadczyć sprawiedliwości seksualnej w prywatnym sektorze dostarczającym szeregu różnych usług (np. magazyny, kluby, restauracje, biura turystyczne, sklepy z bielizną kierujące swoją ofertę do osób LGBT) aniżeli w społecznej zmianie i egzekwowaniu praw osób LGBT (por. Hennessy 2000). W tym kontekście prywatyzacja może odnosić się także do przenoszenia ciężaru odpowiedzialności za zmianę istniejącej sytuacji na jednostkę, w której „prywatnym interesie" powinno leżeć zadbanie o siebie, swoje prawa i przyszłość.

Z drugiej strony - choć były to głosy rzadziej występujące - uznawano, że większa widoczność gejów nie jest zjawiskiem pozytywnym, nie dlatego jednak, że przedstawiani są oni w sposób zachowawczy, ale ponieważ ich tożsamości są niepotrzebnie łączone z seksem. Potwierdzają to słowa jednego z działaczy z Białegostoku - Pawła, który sprzeciwia się umiejscowieniu seksualności w strategiach ruchów queerowych:

[...] Z tego, co zauważyłem, to osoby LGBTQ...głównie geje, nie powiem, jak lesbijki albo osoby biseksualne, bo może, te osoby są niewidzialne, ale ...zazwyczaj się mówi o gejach...i są utożsamiane z seksem, a po co się zajmować seksem? Po co? Przecież są inne, jakby bardziej potrzebujące rzeczy, czy osoby. [ W7_M27_BB_Paweł]

Dostrzegamy tu więc pewien paradoks związany z widocznością osób o nieheteronormatywnej seksualności. Polega ona - z jednej strony - na domaganiu się większej widoczności różnorodnych grup, w tym męskich tożsamości, tak by wzmacniać, po pierwsze, całą społeczność, a po drugie, by czynić możliwą realizację podstawowych postulatów ruchów queerowych. Z drugiej strony osoby, które stają się widoczne, a które przekraczają jednocześnie normy seksualne czy genderowe, 
narażone są na negatywną ocenę i stygmatyzację nie tylko z zewnątrz, ale także ze środka społeczności LGBT (zob. Graff 2010: 594).

\section{W stronę wielu męskości}

Istotnym aspektem pojawiającym się $\mathrm{w}$ zebranych narracjach była, z jednej strony, duża homogeniczność wzorów męskości, obecnych zarówno w działaniach ruchu, jak i w jego produktach, z drugiej zaś nieobecność i przemilczanie kwestii seksu i seksualności. W narracjach tych, podobnie jak w przypadku innych poruszanych tematów, aktywiści nawiązywali do doświadczeń zachodnich, wyraźnie umiejscawiając w nich istotny punkt odniesienia. Obrazuje to, przykładowo, wypowiedź Darka, który - odnosząc się do polskiej historii ruchów queerowych wskazuje na doświadczenia amerykańskie, powielane, jego zdaniem, przez krajowe aktywistki i aktywistów:

[Problem dotyczy] też liczebności jak gdyby tych grup i potrzeby widzialności też grup. Oczywiście, że zawsze było tak, że najpierw to był ruch gejowski, tak? No, nawet historycznie, w Stanach był ruch gejowski, gdzieś tam na marginesie coś lesbijskiego próbowało się odezwać, ale no jakaś tam cząstka, prawda, procent. [W12_M38_KRK_Darek]

Działacze wskazywali ponadto, że o ile w krajach zachodnich powszechna zdaje się być obecność różnego rodzaju subkultur seksualnych, np. społeczności BDSM czy "skórzaków”10, o tyle w kontekście polskim możemy mówić raczej o wytwarzaniu homonormatywnego, pozytywnego wizerunku "kochającej się pary gejów z pieskiem, która seksu nigdy nie uprawia” [W4_M21_KRK_Marek; W4_M23_KRK_Radek] (zob. Duggan 2003).

Radek: To, że ten, jakby mam takie wrażenie, że Polska powiela błędy, polskie społeczeństwo LGBT powiela błędy innych krajów, ale nie powiela ich sukcesów i na przykład powiela ten błąd wewnętrznego wykluczenia. Na przykład geje, jak szukają faceta, to szukają tylko męskiego albo niemęskiego...

\footnotetext{
${ }^{10}$ Nieformalne określenie subkultury gejowskiej - leather community, która, choć wewnętrznie wysoce zróżnicowana, definiowana jest najczęściej poprzez seksualne upodobania do wyrobów skórzanych. Podobnie jednak jak subkultura "miśków", subkultura "skórzaków" analizowana jest w kategoriach wytwarzania i negocjowania męskich tożsamości nieheteronormatywnych, często w opozycji do głównonurtowych przedstawień męskości gejowskiej (zob. Mosher MCoun, Levitt, Manley 2006).
} 
Marek: I spoza środowiska

R: Spoza środowiska

M: Mamy na myśli środowisko miśków ${ }^{11}$

$[\ldots]$

R: Ale to jest też, myślę, że [...] środowisko, czy społeczność miśkowa w Stanach jest najbardziej tolerancyjną społecznością LGBT i tą, która najsilniej działa w ruchu, podczas gdy społeczność miśkowa w Polsce jest silnie wykluczająca względem osób, które nie są miśkami, więc jest tutaj taki bardzo silny opór na inność i to jest opór wszystkiego. Ja jestem, mi się wydaje, że to jest trochę na zasadzie "on jest bardziej inny ode mnie, więc ja jestem dobry, a on jest zły”. Jak zwalić na kogoś...

M: Jak poczuć się lepszym...

R: Tak, poczuć się lepszym, być dyskryminującym wobec kogoś innego, i tutaj myślę, że [na] osoby transpłciowe... [W4_M21_KRK_Marek; W4_M23_KRK_Radek]

W obrębie męskości homoseksualnej - którą, jak wspomniałam powyżej, opisuje się przy pomocy pojęcia subordynacji w patriarchalnym porządku płci - wytwarza się więc nowy porządek, w którym pewne tożsamości zostają uznane za bardziej pożądane, inne zaś spotykają się z przemilczeniem, a nawet z próbą dyscyplinowania. Większość moich rozmówców jest świadoma tych procesów, i na poziomie indywidualnych rozmów wskazuje potrzebę zmian, na przykład w kierunku większego uwidocznienia potrzeb, praktyk i tożsamości mężczyzn nieheteronormatywnych. Kamil, podkreślając różnice pomiędzy aktywistami a aktywistkami, wskazuje, że w przypadku tej pierwszej grupy zastanawia i zaskakuje zupełny brak obecności mężczyzn biseksualnych:

[Zobaczyłem, że] mężczyźni, kobiety...na orientację seksualną jako jakąś tam, nie wiem, drugą przesłankę, i te rzeczy gdzieś na siebie się nakładają, i to jest...kurczę w jakiś sposób trudne...na przykład....a zdaję sobie sprawę, świadomość, że wielu głosów nie ma, nie słychać, nie pojawiają się, a są w jakiś sposób ważne, dlatego, że teoretycznie je reprezentujemy, czy mamy reprezentować. Zupełnie głos biseksualnych mężczyzn się nie pojawia. Nie ma biseksualnych mężczyzn.

\footnotetext{
${ }^{11}$ Termin ten odnosi się subkultury „miśków” - bear community, która zrodziła się w San Fransisco w latach 80. w społeczności gejowskiej i miała stanowić odpowiedź na wizerunek geja utożsamiany najczęściej ze sfeminizowaną postacią męską. Cechy charakterystyczne tej społeczności sprowadzane są najczęściej do afirmacji dużych ciał męskich z mocnym owłosieniem, która bywa interpretowana jako opór wobec dominującego wzorca męskości homoseksualnej (Hennen 2005: 25-43).
} 
Nie znam biseksualnych mężczyzn w środowisku aktywistycznym powiedzmy. [W10_M29_WAW_Kamil]

Biseksualność może być postrzegana jako kategoria bardziej nieokreślona - a co za tym idzie, bardziej „podejrzana” - w porządku społecznym, w którym seksualność i płeć są konstruowane w odniesieniu do siebie i silnie związane w procesach społecznych oraz w codziennych praktykach. Biseksualność nie jest bowiem, w przeciwieństwie do homoseksualności, w sposób jednoznaczny łączona z kobiecością i nie-męskością; nie jest definiowana jako przeciwieństwo męskości hegemonicznych (Steinman 2011). Jej nieokreśloność jest uznawana za przyczynę większej niewidoczności i braku rozpoznania, także wśród społeczności LGBT.

\section{Wnioski: Nowe polityki męskości (?)}

Wyżej opisane refleksje działaczy i działaczek ruchów queerowych w Polsce nie mogą stanowić całkowitego obrazu lokalnego aktywizmu i polityk męskości w nim obecnych. Mogą, jednak, jak sądzę, służyć za punkt wyjścia do rozważań dotyczących przemian i procesów, z jakimi w analizowanych ruchach mamy do czynienia w ostatnich latach. Mimo niezbyt pozytywnego obrazu wyłaniającego z przedstawionych powyżej rozmów, gdy całościowo spojrzymy na działania ruchów queerowych, dostrzeżemy, że same polityki męskości ulegają zmianom, wraz z coraz większą dywersyfikacją kolektywnych działań (działania formalne i nieformalne, działania w różnych miastach W Polsce, adresowane do różnych grup, poruszające różne "wątki" związane z seksualnością nienormatywną).

Starałam się wykazać powyżej, że kwestia płci i tożsamości płciowej jest często poddawana refleksji zarówno przez działaczy, jak i działaczki. Wskazuje się w tym względzie większą widoczność mężczyzn w działaniach różnych organizacji, a także w dyskursie ruchu, przy równoczesnej nieobecności - a raczej mniejszej widoczności - kobiet nieheteronormatywnych i trans-osób. Ponadto same prezentowane męskości nie są wewnętrznie zróżnicowane, jeśli spojrzymy na reprezentację tychże ruchów. Zdaniem moich rozmówców, brakuje na przykład wizerunków mężczyzn biseksualnych, a także przedstawicieli różnych subkultur seksualnych. Interesującym dla mnie wątkiem było także to, że działacze traktowali kontekst państw zachodnich - i zachodnich ruchów społecznych -jako istotny punkt odniesienia i źródła wzorców, z jakich należałoby korzystać. Wyrażali taki pogląd niezależnie od tego, czy sami opowiadali się po stronie większego 
różnicowania praktyk seksualnych i tożsamości męskich oraz włączania głosów różnych osób (także tych, które przekraczają normy genderowe), czy też raczej uznawali potrzebę tworzenia reformistycznych rozwiązań, na przykład poprzez odchodzenie od ekspozycji seksualności i seksu w działaniach ruchu. W zebranych narracjach rodzime, lokalne konteksty właściwie nie występowały jako źródła idei tworzących ramy działań kolektywnych i prób wydobycia nowych polityk męskości. Często jednakże podkreślano bliską współpracę z ruchem feministycznym oraz konieczność podejmowania wspólnych działań na rzecz i równości, i sprawiedliwości, i przeciw dyskryminacji. Nawet jeśli przyjmiemy, że dyskurs feministyczny nie do końca przekłada się na autorefleksyjność związaną z jego pozycją i rolą w ruchach queerowych, to z pewnością może mieć on wpływ na wyłonienie się nowych polityk męskości. Moi rozmówcy wskazali dwie główne ścieżkami, które mogłyby wyznaczać nowe polityki - jedną z nich była większa dywersyfikacja w obrębie tożsamości męskich i seksualnych, która mogłaby stanowić swoiste otwarcie na subkultury seksualne i genderowe; drugą zaś była większa refleksyjność i ciągła dyskusja nad konstruowaniem płci w działaniach kolektywnych z udziałem aktywistów i aktywistek queerowych. Warto jednak podkreślić, że w zebranych narracjach nie zarysował się żaden wyraźny projekt polityk męskości, a sugerowane zmiany prezentowały raczej indywidualistyczne postawy i potrzeby aniżeli kolektywną wizję ruchów queerowych.

\section{BIBLIOGRAFIA}

Basiuk, Tomasz. 2012. Coming out a queer: kontekst amerykański, kontekst polski. W: (red.) Kłosowska Monika, Drozdrowski, Mariusz, Stasińska, Agata. Strategie queer. Warszawa: Difin, s. $60-77$.

Bernstein, Mary. 2009. The strategic uses of identity by the lesbian and gay movement. W: (red.) Goodwin, Jeff, Jasper, James A. The social movements reader. Cases and concepts. Malden: Wiley-Blackwell, s. 264-278.

Bevington, Douglas, Chris Dixon. 2005. Movement-relevant theory: rethinking social movement scholarship and activism. W: „Social Movement Studies: Journal of Social, Cultural and Political Protest" 4, s. 185-208.

Binnie, Jon, Christian Kleese. 2012. Solidarities and tensions: feminism and transnational LGBTQ politics in Poland. W: „European Journal of Women's Studies” 19, s. 444-459.

Buechler, Steven M. 2011. Understanding social movements. Theories from the classical era to the present. Boulder, London: Paradigm Publishers.

Connell, Raewyn W. 1995. Masculinities. London: Polity Press. 
Dempster, Steve. 2011. I drink, therefore I'm man: gender discourses, alcohol and the construction of British undergraduate masculinities. W: "Gender \& Education" 23, s. 635-653.

Duggan, Lisa. 2003. The twilight of equality? Neoliberalism, cultural politics, and the attack on democracy. Boston: Beacon Press.

Dynarski, Wiktor. 2014. Szafa szafie nierówna. Coming Out Day a sprawy trans. "Wiktor Dynarski Blog" 11.10.2013. http://dynarski.pl/post/63718984381/szafa-szafie-nierowna-coming-outday-a-sprawy; dostęp: 30.11.2014.

Einwohner, Rachel L. i in. 2000. Engendering social movements: cultural images and movement dynamics. W: „Gender \& Society” 14, s. 679-699.

Fonow, Margaret M. 1998. Protest engendered: the participation of women steelworkers in the Wheeling-Pittsburgh steel strike of 1985. W: "Gender \& Society", s. 710-728.

Gamson, Joshua. 1997. Messages of exclusion. Gender, movements and symbolic boundaries. W: "Gender and Society" 11, s. 178-199.

Graff, Agnieszka. 2010. Looking at pictures of gay men: political uses of homophobia in contemporary Poland. W: „Public Culture” 22, s. 583-603.

---. 2006. We are (not all) homophobes: a report from Poland. W: „Feminist Studies” 32, s. 434-449.

Gruszczyńska, Anna. 2006. Jak to robią lesbijki w sieci. Zadymiony pokój i ucieczka od branży. W: (red.) Basiuk, Tomasz, Ferens, Dominika, Sikora, Tomasz Parametry pożądania. Kultura odmieńców wobec homofobii. Kraków: Universitas, s. 127-136.

Heaphy, Brian. 2011. Gay identities and the culture of class. W: "Sexualities" 14, s. 42-62.

Heath, Melanie. 2003. Soft-boiled masculinity: renegotiating gender and racial ideologies in the promise keepers movements. W: "Gender \& Society" 17, s. 423-444.

Hennen, Peter. 2005. Bear bodies, bear masculinity: recuperation, resistance, or retreat? W: „Gender and Society" 19, s. 25-43.

Hennessy, Rosemary. 2000. Profit and pleasure. Sexual identities in late capitalism. New York, London: Routledge.

---. 1995. Queer visibility in commodity culture. W: (red.) Nicholson, Linda, Seidman, Steven. Social Postmodernism. Cambridge: Cambridge University Press, s. 142 -183.

Jackson, Stevi, Sue Scott. 2010. Theorizing sexuality. Berkshire: Open University Press.

Johnston, Hank. 2002. Verification and proof in frame and discourse analysis. W: Bert Klandermans, Bert, Staggenborg, Suzanne. Methods of social movement research. Minneapolis, London: University of Minnesota Press, s. 62-91.

Kluczyńska, Urszula. 2011. Męska dominacja i pitka nożna. Analiza medialnych prezentacji W: (red.) Wojnicka, Katarzyna, Ciaputa Ewelina. Karuzela z mężczyznami. Kraków: Impuls, s. 65-89.

Lipowska-Teutsch, Hanna. 2012. Czy lesbijki mają lepiej? W: (red.) Świerszcz, Jan. Lekcja równości. Postawy i potrzeby kadry szkolnej i młodzieży wobec homofobii w szkole. Warszawa: Kampania Przeciw Homofobii, s. 123-138.

Majka, Rafał. 2007/2008. Polityka tożsamościowa organizacji gejowsko-lesbijskich w Polsce a polityka "queer". W: „Interalia" 3. 
McCurdy, Patrick, Julie Uldam. 2014. Connecting participant observation positions. Toward a reflexive framework for studying social movements. W: "Field Methods" 26, s. 40-55.

Messner, Michael A. 1993. "Changing men" and feminist politics in the United States. W: "Theory and Society" 22, s. 723-737.

---. 1998. The limits of "the male sex role": an analysis of the men's liberation and men's rights movements' discourse. W: "Gender and Society" 12, s. 255-276.

---. 1997. Politics of masculinities. Men in movements. Thousand Oaks: Sage.

Miles, Ian. 1989. Masculinity and its discontents. W: „Futures" 21, s. 47-59.

Mosher, Chad M. i in. 2006. Layers of leather: the identity formation of leathermen as a process of transforming meanings of masculinity. W: „Journal of Homosexuality" 51, s. 93-123.

Nagel, Joane. 1998. Masculinity and nationalism: gender and sexuality in the making of nations. W: „Ethnic and Racial Studies” 21, s. 242-269.

Pascoe, C.J. 2005. 'Dude, you're a fag': adolescent masculinity and the fag discourse. W: "Sexualities" 8, s. 329-346.

Robinson, Christine M., Sue E. Spivey. 2007. The politics of masculinity and the ex-gay movement. W: "Gender and Society" 21, s. 650-675.

Santos, Ana Christina. 2012. Disclosed and willing: towards a queer public sociology. W: "Social Movement Studies: Journal of Social, Cultural and Political Protest" 11, s. 2412-254.

Seidman, Steven. 2012. Społeczne tworzenie seksualności. Warszawa: Wydawnictwo Naukowe PWN.

Sikora, Tomasz. 2012. „....czymś innym niż...": queer jako (antyliberalna) polityka pożądania i różnicy. W: (red.) Kłosowska Monika, Drozdrowski, Mariusz, Stasińska, Agata. Strategie queer. Warszawa: Difin.

Sinatti, Giulia. 2014. Masculinities and intersectionality in migration: transnational Wolof migrants negotiating manhood and gendered family roles. W: (red.) Thanh-Dam, Truong, Gasper, Des, Handmaker, Jeff, Bergh, Sylvia I. Migration, gender and social justice: perspectives on human insecurity. Heidelberg, New York, Dordrecht, London: Springer, s. 215-226.

Snow, David A. i in. 2007. Framing the French riots: A comparative study of frame variation. "Social Forces" 86 , s. 385-415.

Standing, Guy. 2014. Prekariat. Nowa niebezpieczna klasa. Warszawa: Wydawnictwo Naukowe PWN.

Steinman, Erich. 2011. Revisiting the invisibility of (nale) bisexuality: grounding (queer) theory, centering bisexual absences and examining masculinities. W: „Journal of Bisexuality" 11, s. 399-411.

Struzik, Justyna. 2010. (Nie)obecność kobiet nieheteroseksualnych w życiu publicznym w Polsce po roku 1989. W: (red.) Frąckowiak-Sochańska, Monika, Królikowska, Sabina, Kobiety w polskiej transformacji 1989-2009. Podsumowania, interpretacje, prognozy. Toruń: Wydawnictwo Adam Marszałek, s. 137-152.

---. 2012. Publiczna socjologia queer. W: „Studia Humanistyczne AGH” 11, s. 93-102.

Taylor, Verta. 1999. Gender and social movements: gender processes in women's self-help movements. W: „Gender \& Society" 13, s. 8-33. 
Taylor, Verta, Nancy E. Whittier. 1992. Collective identity in social movement communities. Lesbian feminist mobilization. W: (red.) Morris, Aldon, McClurg Mueller, Carol. Frontiers in social movement theory. New Haven: Yale University Press, s. 104-129.

---. 1998. Guest editors' introduction: special issue on gender and social movements: part 1. W: "Gender and Society" 12, s. 622-625.

Taylor, Yvette. 2011. Sexualities and class. W : "Sexualities" 14, s. 3-11.

Taylor, Yvette i in. 2010. Theorizing intersectionality and sexuality. New York: Palgrave Macmillan.

Valocci, Stephen. 2005. Collective action frames in the gay liberation movement, 1969-1973. W: (red.) Johnston, Hank, Noakes, John A. Frames of protest. Social movements and the framing perspective. Lanham, Boulder, New York, Toronto, Oxford: Rowman \& Littlefield Publishers, s. $53-67$.

Wojnicka, Katarzyna. 2013. Męskie ruchy społeczne we wspótczesnej Polsce: wnioski i ustalenia. W: „Folia Sociologica" 47, s. 87-103.

Wojnicka, Katarzyna, Justyna Struzik. 2011. Mężczyźni w działaniu. Problematyka męskich ruchów społecznych w Polsce. W: (red.) Wojnicka, Katarzyna, Ciaputa, Ewelina. Karuzela z mężczyznami. Kraków: Impuls, s. 257-278.

Wojnicka, Katarzyna, Ciaputa, Ewelina. 2011. Wprowadzenie: refleksja naukowa nad spotecznokulturowymi fenomenami męskości. W: (red.) Wojnicka, Katarzyna, Ciaputa Ewelina. Karuzela z mężczyznami. Kraków: Impuls, s 7-22. 